\title{
MUST EUROPE BE BELGIAN? On democratic citizenship in multilingual polities ${ }^{1}$
}

\author{
Philippe Van Parijs \\ Universite catholique de Louvain \\ Chaire Hoover d'éthique économique et sociale
}

in Catriona McKinnon \& Iain Hampsher-Monk ed., The Demands of Citizenship, London \& New York: Continuum, 2000, pp. 235-253.

- Partly based on "Quelle philosophie politique pour une démocratie plurilingue ?", in Groupe Avenir UCL, Des Idées et des hommes. Pour construire l'avenir de la Wallonie et de Bruxelles, Bruxelles: Academia - Bruylant, 1999, pp. 11-26.

- Abridged version in Kontingenz und Krise. Institutionenpolitik in kapitalistischen und postsozialistischen Gesellschaften, K. Hinrichs, H. Kitschelt \& H. Wiesenthal eds., Frankfurt am Main: Campus Verlag, 2000, pp. 59-78.

- Dutch translation in Een Vierde Weg ? Links-liberalisme als traditie en als oriëntatiepunt, S. Gatz \& P. Stouthuysen eds., Brussel: VUB Press, 2001, pp. 285-314.

- Italian translation in Nuova Europa e nuovo welfare, Maurizio Ferrera ed., Bari: Cacucci Editore, 2001, pp. 121-149.

- Catalan translation in Idees. Revista de temes contemporanis 9, gener-març 2001, pp. 27-41.

"Let us once again cast a glance upon Belgium, our constitutional 'model state', the monarchical El Dorado with the broadest 'democratic' basis, the university of the Berlin statesmen and the pride of the Kölnische Zeitung." Thus starts an article published by Karl Marx (1848: 333) in the Neue Rheinische Zeitung. Most of the article is devoted to documenting the growth of poverty and crime in the Modellstaat Belgien, the allegedly exemplary "model democratic state of Belgium" and it persuasively suggests that, whatever its economic performance, there is a seamy side too to liberal capitalism. Although Marx's article could have been published under the title I rather frivolously proposed for this contribution, my purpose is rather different from his, and unlike his no doubt would have been, I am

1 This contribution was prepared within the framework of the inter-university research project "The New Social Question" (Belgian Federal Government, Prime Minister's Office, Federal Office for Scientific, Technical and Cultural Affairs). Earlier versions were presented as a Visiting Felllow's talk at All Souls College (Oxford, May 1998) and at the Conference "The Historical Perspectives of Republicanism and the Future of the European Union" (Siena, 23-27 September 1998). A slightly different version appears in a Festschrift in honour of Claus Offe (Contingency and Crisis. The Politics of Institutional Design in Advanced Capitalism and Post-Socialism , Karl Hinrichs, Herbert Kitschelt \& Helmut Wiesenthal eds., Frankfurt am Main: Campus Verlag, 2000). 
already warning you that my answer will be yes. Sounding more ludicrous, the claim I shall thereby be making is likely to arouse less concern than if in the question "Belgian" had been replaced by "German", or "French", or "British", or even "Dutch". Moreover, what I shall invite you to take seriously as a desirable institutional future for the European Union is not - arrogantly - Belgium's current Ego, but, as it were, its Super-Ego, not its present institutional structure, but what I believe it must urgently be moving to.

More specifically, what I shall do in the bulk of this presentation is sketch two fundamental challenges to which Belgium's institutions need to respond in a coherent way. Finding such a response is by no means obvious, if only because the two challenges seem to generate conflicting demands. But the very survival of the country and - what is more important - the preservation of the combination of extensive freedom and generous solidarity, which the country has been able to develop, along with its neighbours, in the course of the twentieth century, hinge on identifying and implementing such a response. Very schematically, the discussion of possible responses to the first challenge will show how the demands of democratic citizenship foster the territotial partition, along linguistic lines, of what constitutes the last plurilingual sovereign remnant of the Habsburgs' multilingual Empire. But if citizenship is not to become vacuous in a globalised market, I shall next argue even more briefly - in connection with the second challenge, we must resist this democratic impulse and attempt to restructure the country's institutions so as to make them lean but powerful, and durably compatible with the massive autonomy of essentially unilingual regions. On this background, I shall finally suggest that the European Union as a whole, though coming from the opposite direction as it were, increasingly faces the same predicament and I shall sketch how an analogous response needs to be thought about and put into place.

\section{The democratic challenge}

The first challenge can be presented in many ways. I shall adopt the version given to it by John Stuart Mill in an ominous passage of the 16th chapter of Considerations on Representative Government. After having sympathetically noted that "the Flemish and the Walloon provinces of Belgium, notwithstanding diversity of race and language, have a much greater feeling of common nationality than the former have with Holland, or the latter with France", Mill pronounces his famous (near) indictment of multilingual democracies: 
"Free institutions are next to impossible in a country made up of different nationalities. Among a people without fellow-feeling, especially if they read and speak different languages, the united public opinion, necessary to the working of representative government, cannot exist. The influences which form opinions and decide political acts are different in the different sections of the country. An altogether different set of leaders have the confidence of one part of the country and of another. The same books, newspapers, pamphlets, speeches, do not reach them. One section does not know what opinions, or what instigations, are circulating in another. [...] For the preceding reasons, it is in general a necessary condition of free institutions that the boundaries of governments should coincide in the main with those of nationalities." (Mill 1861: 291-294, emphasis added).

Leaving out a number of nuances and qualifications, I shall give Mill's claim the following stark formulation: "No viable democracy without a linguistically unified demos." This claim I shall here simply call the democratic challenge.

For a long time, the process described by Mill was hardly noticeable in Belgium, basically because the country was ruled, North and South, by a Frenchspeaking elite. But it is now in full swing. Let me just mention three indicators. ${ }^{2}$

2 None of these is perfect, as there are no suitable comparable data that would enable us to put the putative trends in perspective. The underlying trend is of course supposed to relate to the knowledge of each other's language. But the last census which was allowed to collect and publicise linguistic data took place in 1947. A February 1999 Survey (by INRA Marketing Unit, Brussels, on behalf of the association TIBEM Tweetaligheid in beweging - Bilinguisme en mouvement) gives some clues as to where we are and where we are going. Thus, when breaking down into three age groups the answers to the question "Can you speak correctly the other national language?", the following pattern emerges. The percentage of subjects with Dutch as mother tongue who say they can speak French correctly is rising from 15\% in the older category (55 or more) to $31 \%$ among the $35-54$ and to $35 \%$ among the 15-34. The percentage of francophone subjects who say they can speak Dutch falls from $19 \%$ among the old to $12 \%$ among the $35-54$ and $4 \%$ among the $15-34$. These survey results are somewhat misleading, mainly because the sample used significantly over-represents the Brussels area (about one million people, mostly francophones), in which the francophones's knowledge of Dutch is far higher than in Wallonia (about three and a half million people). However, correcting this bias would further depress the level of the second curve, but could hardly affect its slope. Both the proportion of Flemings who learned French and the proportion of francophones who learned Dutch have practically doubled from the older to the younger group, but whereas, among those who have 
While the watching of Flemish TV by Walloons has always been very low, the watching of the French-language Belgian channels by Flemish viewers is now also down to $0.7 \%$ of their TV time (BRTN 1996). Even in Brussels, $85 \%$ of francophones say they never read a Flemish newspaper (Fondation francophone de Belgique 1997: 23). And between 1954 and 1993, controlling for distance, the probability of moving from a Walloon commune to a Flemish commune or vice versa has dropped from one half to one third of the probability of moving from one commune to another within the same region (Poulain \& Foulon 1998: 55-56).

"The outcome", as sociolinguist Kas Deprez (1998) puts it, "is that a genuine Belgian we-feeling is no longer possible". Or again, in the equally Millian formulation of political scientist Wilfried Dewachter (1996: 136): "The country's other community is practically a foreign people. It is rather difficult for a political system to keep functioning satisfactorily with such mutual ignorance and hence such lack of mutual understanding of the two halves of the country." No one who has been following Belgian politics in recent decades can deny that this is an increasingly serious problem. No one who has read Mill's analysis can fail to suspect that this problem does not arise from an idiosyncratic defect of Belgium's populace, but is paradigmatic for all multilingual democracies. With about 6000 living languages in the world, with 211 sovereign states to accommodate them, and with formal democracy slowly gaining ground, the problem is definitely worth more attention than the traditional focus on the "standard" case of uni-lingual democracies has encouraged.

What can be done about it? How can Mill's condition of a unified demos be fulfilled? Before considering what can plausibly be regarded as the only four options, it is important to tease out a crucial ambiguity in the formulation I have given to our democratic challenge. As was neatly brought out in a controversy between Dieter Grimm (1995) and Jürgen Habermas (1995) about the European Union's democratic potential, a "unified demos" can be understood either as a "homogeneous ethnos" or as a "common forum". In the former interpretation, which can plausibly be traced back to Carl Schmitt (1926: 14), democracy is only viable for a homogeneous people, one which needs to possess, not racial purity, but a shared culture and identity. Language matters here as a central component of a people's culture. In the second

learned a second national language, the proportion of those who say they can speak it correctly has increased somewhat among the Flemings, it has dramatically decreased among the francophones, presumably because many of them choosing to learn English as their second language, and Dutch only as their third language. 
interpretation, which I shall take to be the best construal of Mill's thought, democracy is only viable for a communicating people, one which may not share a single culture or identity in any thick sense, but which possesses a common space for discussion and decision-making. Language matters this time simply as a medium of communication. As the linguistic conditions for a common forum are likely be less stringent than the linguistic conditions for a homogeneous ethnos, this clarification may turn out to be crucial if one is not to unnecessarily foreclose some otherwise promising options.

\section{Generalised Unilingualism}

The most obvious way of meeting Mill's condition for a viable democracy obviously consists in adopting a single language throughout the country. There is no doubt that other countries have successfully pursued this strategy. Thus, in 1789, French was the mother tongue of less than $50 \%$ of the population then living in the territory that now forms France. There is no doubt that parts of Belgium's political elite was tempted to adopt an analogous strategy, toughly expressed in a quotation often attributed to Charles Rogier, one of Belgium's first Prime Ministers (1847-1852) and a powerful liberal politician throughout the first half century after Belgium's independence:

"The first principles of a good administration are based on the exclusive use of a language and it is obvious that the Belgians' sole language must be French. To achieve this outcome, it is necessary that, for a while, all civil and military functions should be entrusted to Walloons and Luxemburgers: in this way, being temporarily deprived of the advantages attached to these functions, the Flemings will be forced to learn French, and the germanic element will be gradually destroyed in Belgium." 3

3 As already shown by the Flemish historian Leonard Willems (1902: 59-69), the sole source for this quotation is a Dutch-language lecture made in Ghent in 1866 by some Frans Gerard: the first part of the quotation there only appears in indirect style, while the second part is only an interpretation of Rogier's thought by the author of the lecture. This has not prevented the passage from being quoted (generally in French) as authentic up to the present day: see e.g. De Ridder (1988: 106), Beelen \& al. (1993: 19), Brans (1993: 25), etc. Nor does it prevent it from expressing what many members of the French-speaking bourgeoisie more or less secretly thought, including possibly Rogier himself, who in 
I should add that there was at the time no lack of high-minded justifications for this tough approach. Friedrich Engels, for one, did not think much of the defence of weaker languages and cultures: "By the same right under which France took Flanders, Lorraine and Alsace, and will sooner or later take Belgium - by that same right Germany takes over Schleswig; it is the right of civilisation as against barbarism, of progress as against stability." (Engels 1848: 423) And Mill himself cannot be said to have lacked sympathy for this first way of meeting the democratic challenge he so forcefully formulated:

"Experience proves that it is possible for one nationality to merge and be absorbed in another: and when it was originally an inferior and more backward portion of the human race, the absorption is greatly to its advantage. Nobody can suppose that it is not more beneficial to a Breton, or a Basque of French Navarre, to be brought into the current of the ideas and feelings of a highly civilised and cultivated people - to be a member of the French nationality, admitted on equal terms to all the privileges of French citizenship, sharing the advantages of French protection and the dignity and prestige of French power - than to sulk on his own rocks, the half-savage relic of past times, revolving in his own little mental orbit, without participation or interest in the general movement of the world. The same remark applies to the Welshman or the Scottish Highlander, as members of the British nation." (Mill 1861: 294-5).

Yet, Belgium did not follow this path. Why not? Basically because there were sufficiently numerous, powerful and organised Flemish people who saw that it was in their collective interest to claim equal rights for their own language, or at any rate for a language far closer than French to their native dialects. There were therefore two competing processes of linguistic nation-building and one of them lost to the other. On one side, there was the central authority of an industrialising country with a strong interest in expanding an educated and mobile work force through a linguistically uniform administration, army and - above all - school system. This is the basic mechanism at work in the process famously described by Ernest Gellner (1983: 139-140) as a transition from Kokoshka to Modigliani, from a linguistic map of Europe that looks like a mess of coloured patches to one in which nearly uniform surfaces are neatly separates by thick black lines representing political boundaries. On the other side, there is the struggle to gain official recognition within a restricted area for a language so far unrecognised. To use Benedict Anderson's (1993: 615-617)

1847 felt he had to publicly deny in Parliament that he intended to "walloniser les Flandres" (Willems 1902: 57). 
illuminating metaphor, this works as a tariff, a customs barrier: to the people coming from the centre, the local people can now say: "Do come, trade, work, administer here, but henceforth you'll need the humility to learn speak our language rather than expect us to speak yours. This amounts to the erection of new borders, to the drawing or strengthening of new lines, which does not prevent Modiglianisation but forces it to operate on a smaller scale. In this case, unlike many others, the resistance won. And it is right that it should have won. Why? The answer is not straightforward. There is, after all, no lack of efficiency-based, and even equalitybased arguments in support of linguistic homogenisation, of countries bulldozing out of existence their minority languages. My condoning of resistance does not rely on any alleged right for languages to survive, nor on the assumption that we owe to our ancestors to preserve their culture, nor even on the aesthetic value of linguistic diversity. There are, I believe, only two types of arguments which can carry significant weight. One is consequentialist and relates to the long term. The other is justice-based and concerns the transition period only.

There are undoubtedly strong efficiency advantages associated with the ease of communication and movement which linguistic homogeneity makes possible. But there are two effects of linguistic diversity which may plausibly, under some circumstances, more than offset these advantages. Given the nature and reach of present-day media, linguistic diversity is the firmest, and increasingly the only serious protection of cultural diversity, and the latter permits a diversity of experimentation in private and collective life, from which the general interest may well, in the long run, benefit. Secondly, in an increasingly globalised world, linguistic diversity is the firmest, and increasingly the only serious break on the mobility of people. It is in this sense a precious population stabiliser, at any rate if one regards massive migrations as undesirable, whether because of its propensity to dislocate local communities or because of its jeopardising the economic and political viability of institutionalised solidarity. The first of these two arguments is rather speculative, while the second one is contingent on a specific view of what counts as a good or just society. Both only apply to cases in which it is a less widely spread language that is losing ground.

The second, justice-based type of argument does not have those limitations, but it is necessarily restricted to the short term: it relates to what unavoidably happens in the transition from a situation of linguistic diversity within a territory to one in which one of the pre-existing languages is imposed as the official language. Having a mother tongue different from the one adopted as the official language puts one at a multiple disadvantage. People in that position have to bear the heavy cost of 
acquiring proficiency in a foreign language. They are handicapped, relative to natives of the official language, in economic and political competition. Most seriously perhaps, their self-respect is under pressure as a result of the subordinate, inferior status given to something as deeply associated with themselves (in other people's eyes and their own) as their mother tongue. Admittedly, this injustice is limited to the transition period: native French-speaking Bretons and native Englishspeaking Irish people do not suffer from it. But if the transition is short, owing to some vigorous unilingualism policy, the injustice is very acute. And if the transition is milder, it will affect many generations. Admittedly too, the injustice could in principle be alleviated in various ways (though it seldom is in any of them). The native speakers of the dominant language could pick up at least the full financial burden of language learning. Reverse discrimination measures could secure a fairer access to jobs and promotions to the speakers of the dominated language. But even if the cost of learning were fully compensated and discrimination fully neutralised, there would remain the serious prima facie injustice associated to the unequal respect manifested in the sharply unequal public recognition of the official and the subordinate languages. Of course, all things considered, this justice-based argument may sometimes need to give way, for example if the linguistic community concerned is very small, but it provides nonetheless the strongest and most general reason for condemning linguistic assimilation and justifying resistance to it.

Whether or not it is to be condemned, there is in any case no one in Belgium today, however attached to national unity, who still believes that this first strategy is the way to go - not even in the other direction. After all, over $60 \%$ of Belgium's population now have Dutch as their mother tongue, and they are estimated to produce about $70 \%$ of the national product. But even a very timid attempt by the Flemish regional government to slightly erode the francophones' rights to receive administrative documents in French in six communes around Brussels has been met by fierce resistance, indeed was the subject of an official complaint to the Parliamentary Assembly of the Council of Europe on the ground that it violated the fundamental rights of minorities. Hence, we might as well forget generalised unilingualism. Too bad! It would have been so simple.

\section{Generalised bilingualism}

The second strategy for meeting a bilingual society's democratic challenge consists in banking on bilingualism. It comes in two variants, profoundly different from one another, but both bound to fail, basically because of the conjunction of the 
same two trivial empirical facts: (1) For two people to communicate with one another, it is enough that one of them should know the other's language. (2) Learning a foreign language is a heavy, costly job, and getting unmotivated children or teenagers to learn a foreign language is a hopeless project.

In the soft or liberal version, bilingualism is required of the territory without being required of the people. This means that the administration, the courts, the political assemblies and above all the schools are required to function in either language throughout the country, depending on what the preferences of (a sufficient proportion of) the local population happen to be. However, this soft bilingualism is just a milder, slower, more covert but no less inexorable form of generalised unilingualism. This is so because of a process perceptively described by Jean Laponce $(1984,1993,1996)$ : the more kindly people behave towards one another, the more savagely languages treat each other. Languages can coexist for centuries when there is no or little contact. But as soon as people start talking, trading, working with each other, courting each other, having children together, one language gradually drives out the other one. The formal equality of Belgium's two languages officially recognised in 1898 did little to slow down the Frenchisation of Brussels and other Flemish cities in the early part of the 20th century. Spreading form the urban centres, the "oil stains" steadily kept growing as a result of parents choosing the "best" schools for their children and mixed couples choosing the "easiest" language for internal communication. Hence, the hard, authoritarian, centralised, deliberate, topdown Gellner-type mechanism and the soft, liberal, decentralised, spontaneous, bottom-up Laponce-type mechanism are simply two very different ways of achieving in the end the same outcome, the gradual extinction of a linguistic community.

The same cannot be said about the hard, authoritarian version of bilingualism, the only one that takes bilingualism seriously as it requires the people, not only the territory, to become bilingual. To enforce a widespread real competence in the second language, one could think, for example, of making it a strict condition for graduating from secondary school or entering higher education of any sort, or a prerequisite for applying for all public sector jobs, possibly even some private sector jobs, throughout the country, whether or not the performance of the job is likely to involve a significant use of it. Jules Destrée, the historical leader of the Walloon and socialist movement, considered this possibility: : It is in Brussels that the fabulous theory of full bilingualism was born. Belgium is a bilingual country, hence all Belgians must be bilingual. By teaching French to the Flemings and Flemish to the Walloons, we shall achieve the genuine national unity." His assessment is 
unambiguous: "This theory is imbecile." (Destrée 1923: 127). This fierce hostility is not hard to understand. Firstly, on the background of the asymmetrical, soft bilingualism that was prevailing in Belgium in Destrée's time, it is clear that hard bilingualism would give a systematic advantage to Flemings, the natives of the dominated language, whose competence in the dominant language was (and still is) far greater than the Walloon's competence in Dutch. Secondly, Destrée could not fail to be aware of the massive, indeed prohibitive cost of motivating and teaching pupils, of motivating and training a sufficient number of teachers, for the learning of a language which there is little point in learning since the others will anyway be learning theirs. We are thus back to the double empirical fact mentioned at the start of our discussion of generalised bilingualism: it provides the fundamental reason why its hard version too is an unpromising prospect.

\section{Non-territorial separation}

Let us not despair yet. For as we continue exploring the space of logical possibilities, we shall have no difficulty identifying a third straightforward way of satisfying Mill's condition of a linguistically unified demos. It consists in gathering all the people who speak the same language, wherever they live throughout the country, into a political entity, a Gliedstaat, and in devolving powers massively to this level. This is an extreme version of an idea put forward at the beginning of the century by Karl Renner, an Austrian social-democratic thinker and politician who became president of Austria after World War II. In his remarkable Das Selbstbestimmungsrecht der Nationen (1918), he tried to work out in detail presumably for the first time in history - democratic institutions for an irreducibly multinational state. What he proposed was a combination of territorial federalism and what he called personal federalism. Each of the eight nations comprised in the Austro-Hungarian empire (Germans, Czechs, Poles, Hungarians, Slovenes, Slovaks, Croats, Italians) were to be given their own Parliament and granted full autonomy in matters of culture, education and at least some aspects of social policy, with matters of common interest settled through negotiation between the representatives of the various nations.

The Austro-Hungarian Empire soon fell apart, and Renner's scheme was therefore never tried in the context for which it was meant. But some form of nonterritorial federalism was tried elsewhere, for example in Estonia in 1925, in Cyprus in 1960 or in South Africa in 1984, never with great success. The only place where it subsists is precisely in Belgium, in the limited but still quite recognisable form of its 
federalism of communities: next to its three regions - Flanders, Wallonia and Brussels - , Belgium has three communities - Flemish (comprising all inhabitants of Flanders and the Dutch speakers of Brussels), German (comprising the 60.000 inhabitants of a handful of German-speaking communes in the East of Wallonia) and French (comprising all the other inhabitants of Wallonia and the French speakers of Brussels). The very fact that Belgium is still in trouble shows that this scheme has not fixed it. But this might be because the variant of non-territorial segmentation it has adopted is not radical enough. One can easily think - and some people do - of further expanding the powers of the communities, at the expense of either the regions or the federal government. One can also think of simultaneously and massively expanding the territory whose inhabitants can belong to either community, more precisely by making it possible not only for the inhabitants of Brussels (as is the case now, but also for those of the country's other two regions (Flanders and Wallonia), to be members of either the French or the Flemish community. What the existing weak version of non-territorial federalism cannot achieve, perhaps this more radical version will.

Not much reflection is needed to conclude that it will not. A first intrinsic difficulty can be compactly phrased in terms of a dilemma between linguicide and apartheid. For there can be a soft, choice-based conception of membership in a community, and a hard, ascriptive one. In the former interpretation, each household is free to choose the community it belongs to, as reflected, for example, in the choice of a school for its children. But there is then no reason why the weaker community should not feel under permanent threat - exactly like in the case of soft bilingualism, though with a major proviso: with economically unequal communities, the conversion speed from one community to the other may be further increased, as membership of the richer community is likely to come with a number of material advantages, but it may also be slowed down or reversed, if the community with the weaker language is the more affluent one. ${ }^{4}$

There is of course a way of avoiding the strains generated by the fear of losing ground. It consists in depriving households of the right to choose which community they belong too. This is exactly what the hard version of non-territorial federalism does: which community you belong to - and hence which school you and your

${ }^{4}$ For this reason, a federalism of communities provides an imaginable mechanism (the only one under present conditions) for a reconquest of Brussels by Flanders (whose GDP per capita is nearly $30 \%$ higher than that of Wallonia). See Van Parijs (1999) for a sketch of how it would work. 
children attend, which health insurance package you receive, which sports facilities you have access to, which family law you are subjected to, etc. - is strictly determined by your native tongue. As one's native tongue is hardly less a matter of arbitrary luck than one's racial features, and as membership of different communities can be associated with very unequal packages of entitlements, it is clear that this ascriptive variant of far-driven non-territorial federalism is no less repugnant than the racial version of it imagined for South Africa in 1984.

This dilemma between (soft) linguicide and (linguistic) apartheid constitutes only one of two decisive difficulties for the strategy of non-territorial separation. The second one stems from the irreducibly spatial nature of any coherent, comprehensive project for a political community. There is a tremendous structural strain inherent in any set up in which distinct political communities elaborate and discuss their own projects separately and then need to negotiate and compromise with each other on countless issues, because they happen to share the same territory. For this reason too, non-territorial separation is not that promising after all as a strategy for addressing our democratic challenge. Is there any other candidate? Reluctantly, it seems, only one: territorial separation.

\subsection{Territorial separation}

Underlying the rejection of each of the previous three options, there is not only the assumption that languages must be protected, but also that their protection requires enforcing some sort of territoriality principle. With some minor qualifications, this thesis is Laponce's (1984) central message. It also provides a plausible explanation for why relations between linguistic communities have on the whole been significantly better in Switzerland than in Belgium, Canada or Spain, let alone in Sri Lanka, East Timor or Kosovo ${ }^{5}$ The territoriality principle amounts to telling any newcomer (whether by birth or immigration): "Whatever your mother tongue, you are welcome to settle here. But if you do, you will have to learn the local language, which will be the exclusive language of public administration, of political

\footnotetext{
5 In a country such as Switzerland, writes for example Alexandre Papaux (1997: 133), judge at
} the Court of the Canton of Fribourg, "it is absolutely necessary to determine the territorial domains of each language and to protect autochtonous linguistic communities, whether or not they are threatened, in their traditional spreading areas. For the persistence of national languages cannot conceivably be guaranteed without ascribing to each an exclusive territory." 
communication and most importantly of publicly subsidised education." Once this principle is firmly in place, our democratic challenge can be met through a massive devolution to suitably drawn regions, at the limit by the territorial partition of the country. In contrast with non-territorial separation, there is here no dilemma between linguicide (languages are entrenched) and apartheid (all inhabitants of a territory belong to the same political community, with equal social and economic rights), nor does the irreducibly spatial dimension of projects and policies constitute a problem if boundaries are sensibly drawn.

For this solution to work smoothly, however, one obviously requires a significant degree of pre-existing linguistic homogeneity. For $99 \%$ of Belgium's territory, this is not too bad, precisely because the territoriality principle has been in place, with some significant exceptions, since the language legislation of 1932. Regional unilingualism was then adopted for most of the territory outside the national capital, as a compromise between soft and hard bilingualism, to which, for the reasons sketched above, Flemings and Walloons were, respectively, bitterly opposed. The exceptions made by the 1932 compromise were at the source of further trouble. Some of them were later erased, most prominently when the borders were permanently fixed, instead of left alterable in the light of the linguistic census (1962) and when the Université catholique de Louvain, Belgium's largest French-language university, was expelled from the Flemish town of Leuven in which it had been located for over five centuries (1969). But the main exception persists. As Jules Destrée (1923: 182) put it, "When separatists are asked what will be done, in case of partition, with Brussels and the Congo, they are very embarrassed, and this is indeed the big stumbling block of any fully separatist scheme." Congo has since taken care of itself - in this respect at any rate - , but what about Brussels? Has its linguistic situation evolved so deeply in recent decades that it no longer constitutes a stumbling block. I believe it has, and that the future lies, in this respect, neither in an absorption of Brussels, along with Wallonia and possibly the Grand Duchy of Luxemburg, into a re-drawn Belgique; nor in a "reconquest" of Brussels by Flanders; but in a full recognition of the increasingly sui generis nature of "the people" of Brussels. Rather than filling out the crucial details of this territorial devolution scenario, which I regard as the best response to Mill's challenge in the Belgian context, I shall now turn, far more briefly, to the second challenge.

\section{The redistributive challenge}


This second challenge can be formulated in very general terms by stating that a number of major, irreversible trends, most of them closely connected to so-called "globalisation", have been converging to increasingly turn states into firms. States can no longer count on "their" capital, "their" workers or "their" consumers, but they have to compete with each other to attract or retain savings and investment, skilled labour and the willingness to buy their products. As the pressure stemming from this competition intensifies, the pattern of public expenditure that can be sustainably achieved by each state is bound to be deeply modified. In particular, its ability to reduce the income inequalities that emerge from the operation of the market will be dramatically curtailed. ${ }^{6}$ This is our second challenge, which I shall call the redistributive challenge.

This is not the place to dwell on the general nature of the underlying trends, their causes and consequences. I shall restrict myself to indicating why the challenge is bound to take a particularly acute form in case Belgium were to fall apart, taking as a point of departure the following paradoxical fact. Among Belgium's eleven provinces (five in Flanders, five in Wallonia, and the region of Brussels), the province of Brabant wallon, to the South of Brussels, is at the same time the richest and the poorest. It is the richest in terms of average household income as recorded for income tax purposes. It is the poorest in terms of GDP per capita. The explanation is not that, since the Clabecq steel works were down-sized, the province's biggest employer is one whose productivity might be suspected of being abysmally low, namely my own University. It is rather, quite simply, that the province in which one works need not be the province in which one lives. Therefore, many people who are currently earning high incomes in Brussels or have done so in the past, can easily choose to retire in Brabant wallon or to commute daily into Brussels. Since Brussels is completely surrounded by the Flemish region, note that the many people who do such commuting either by car or by train - many also from more remote Walloon provinces - travel every day trough the three regions which territorial partition would make formally autonomous.

${ }^{6}$ For a vivid description of the transformation of states into firms, see Strange (1992). The extent to which "globalisation" is a novel phenomenon and the extent to which it is inimical to the thriving of large welfare states are hotly debated issues (see e.g. Garrett 1998, Vandenbroucke 1998, Scharpf 1999 for useful overviews). But even those who support the view that investors do not necessarily dislike big welfare states cannot deny that, if they are to cope with the new context, the latter will be under pressure to reshape themselves in such a way that, whenever there is a marked conflict, the concern with a fair distribution will have to yield to the concern with competitiveness. 
This paradoxical fact and its explanation should suffice to enable you to imagine how acute fiscal competition would be in the vicinity of Brussels - and with efficient transport, the area within daily commuting distance of Brussels can easily comprise half of Belgium's population and three quarters of its GDP - if each of Belgium's three regions were given a great degree of fiscal autonomy, and even more if they became as independent of each other as EU member states can be. Firms can choose to settle or relocate in any of the three regions while hardly modifying the distance from their employees' residences or their business partners' sites. Households can also choose to stay in, or move to, any of the three regions without a major impact on distances from their jobs, relatives or friends. There is therefore much to gain from a sharp and resolute lowering of tax rates in order to lure prosperous businesses and affluent taxpayers - and much to lose from sticking to high rates. It would therefore not take long for the fiscal competition triggered by fiscal autonomy to unravel the elaborate and comparatively generous redistribution systems slowly built up in the course of Belgium's history. The termination of transregional solidarity as a result of the partition process would thus be compounded by a fast erosion of intra-regional solidarity.

Of course, nothing would in principle prevent autonomous regions from striking deals with one another in order to organise inter-regional redistribution and protect intra-regional redistribution at the levels that would have prevailed in the absence of partition. But the limits and fragility of such confederal system are notorious. The authors of the Federalist Papers observed the workings of the confederal constitution of the United (Dutch) Provinces of their time and were not impressed: "Such is the nature of the celebrated belgic confederacy, as delineated on parchment. What are the characters which practice has stamped upon it ? Imbecility in the government; discord among the provinces; foreign influence and indignities; a precarious existence in peace, and peculiar calamities from war. It was long ago remarked by Grotius that nothing but the hatred of his countrymen to the house of Austria kept them from being ruined by the vices of their constitution." (Hamilton \& al. 1788: 170). There is no reason to expect a 21st century Belgian confederation to be any less "imbecile" than the "belgic confederacy" of the 18th century pilloried in the Federalist Papers.

\section{A four-pronged package}

Although far more would need to be said to show how serious this second challenge is and how hopeless it would be to try to tackle it through 
intergovernmental deals, enough has been said to see the emergence of a threatening tension. On the one hand, one cannot have a viable democracy in a multilingual society - this is the democratic challenge. On the other hand, one cannot have generous redistribution in a small open economy - this is the redistributive challenge. To make democracies more unilingual, and thereby alleviate the first difficulty, one needs to devolve power to linguistically more unified territories. But the more one decentralises redistributive powers, the tighter the economic constraints on redistribution, and hence the more acute the second difficulty. In a multilingual area, here lies therefore an undeniable tension, an unavoidable trade off between smooth democratic functioning and generous intra- and inter-regional solidarity. But there are also ways of softening the trade off. Imagining, implementing these ways is what I view as Belgium's central task in the years ahead. The guiding idea must be to strengthen the linguistic significance of borders while weakening their socio-economic importance.

More specifically, what is needed in the case of Belgium is a coherent package of reforms including at its core the following four: (1) a vigorous protection of the linguistic integrity of Flanders and Wallonia (though not of Brussels); (2) a reform of (key sectors of) Belgium's welfare state that combines a central collection of resources with capitation grants to the three regions, each in charge of the conception and management of its own health and education systems; (3) a reform of the electoral system that induces vote pooling across the linguistic border, instead of perpetuating the current state of affairs, in which unilingual parties fish for votes among in only one of the two communities; and (4) the gentle fostering of a common forum of discussion which will increasingly be, not in French (the common medium in the past and the majority language in Brussels), nor in Dutch (the majority language in Belgium), nor in German (the third national language and the majority language in the European Union), but in the emerging first universal lingua franca. ${ }^{7}$

I am convinced that this is also the sort of (four-pronged) package that Europe will, mutatis mutandis, increasingly need. In a nutshell, my diagnosis is as follows. On the one hand, the pressures of fiscal and social competition will build up, as

7 The first of these four components has been motivated at length above; the second one is further spelled out in Van Parijs (1999); the third one is presented and defended in Van Parijs (2000b) and the last one is laterally vindicated in Van Parijs (2000a). All four are developed in a book in progress under the provisional title La Dynamique des peuples et les exigences de la justice. La Belgique comme avenir de l'Europe. 
savings, consumer demand, firms and high-skilled professionals become increasingly mobile. On the other hand, the strains arising from so-called asymmetric shocks and divergence within an economic and monetary Union will start making themselves felt as regional specialisation deepens, without labour migration providing an adjustment mechanism - as it does in the US -, because of Europe's linguistic diversity and the importance (argued for above) of preserving the latter. In this context, the need will develop for massive and systematic transfers across the borders of the EU's member states - at least if Europe does not want to perform even more poorly than the US do today in terms of (freedom-friendly) solidarity. However, such transfers will only prove sustainable (1) if they are consistent with the unilingual (sub)national polities' claim to organise the fine structure of their solidarity systems as they see fit; (2) if they take a very simple form that minimises moral hazard while preserving autonomy, typically capitation grants to governments or citizens, centrally funded out of a common tax base; (3) if they can rely on electoral institutions that structure the political game at EU-level along ideological rather than national lines, and (4) if they can be discussed and justified in a common forum of discussion using a language understandable all over Europe. ${ }^{8}$

${ }^{8}$ Following Grimm (1995: 295-6), Kymlicka (1999: 119-25) rightly stresses the importance of the language factor for the possibility of European democracy. But his resulting pessimism can only be justified if he overlooks much of political life in multilingual countries, i.e. in most countries in the world. "Put simply", Kymlicka (1999: 121) writes," democratic politics is politics in the vernacular. The average citizen only feels comfortable debating political issues in their mother tongue. As a general rule, it is only elites who have fluency with more than one language, and who have the continual opportunity to maintain and develop these language skills, and who feel comfortable debating political issues in another tongue within multilingual settings." For unilinguals, and in particular for unilinguals in unilingual countries, this will sound only too plausible. But in the majority of countries, which happen to be multilingual, many people have no option, if they want to participate in national politics at all, but to do it entirely, or mainly, in a language different from their mother tongue. Some of them are even pretty good at it. Think of Nelson Mandela. True, such active political participation at the national level is restricted to an elite. But is it more than an elite that "feels comfortable debating political issues" even in its mother tongue? Learning the tone, concepts and tricks which make for effective participation in "one's own" mother tongue is hardly less difficult than learning another language to which one is frequently exposed anyway. More seriously, the people whose mother tongue is different from the common political medium are at a strong disadvantage in political communication and competition, and this constitutes an undeniable source of unfairness which cannot easily be remedied. But this should not be a decisive objection either to EU-wide democracy, 
Belgium is coming from a situation in which redistribution was operating at the global level, but without adequate recognition of the consequences of having two separate democratic spaces. The task is to adequately accommodate this separation, while preserving the sustainability of global solidarity. In Europe, separate national democratic spaces have been recognised all along, but redistribution is not (more than marginally) organised at the global level. The task is to create the conditions for global solidarity, while protecting the autonomy of separate national democratic forums. For such global solidarity is required if the redistributive challenge is to be met under contemporary conditions. And if the democratic challenge is to remain satisfactorily met, this must go hand in hand with protecting linguistically homogeneous territories and their autonomy. It is therefore not surprising that the set of conditions spelt out above in the European case should bear close resemblance to the policy package advocated earlier in the Belgian case. If Belgium can successfully adopt such a package, then it will make it far more credible that Europe can and must move in this direction too. ${ }^{9}$

This should have clarified in which sense it may not be altogether ludicrous to claim that Marx's Modellstaat Belgien will soon deserve to be, if not "the University of the Berlin statesmen", at least a model worth thinking about and being inspired by for those who believe in the importance of preserving not only multilingualism

providing the teaching of a common second language can be effectively and widely organised. As made clear in his reply to Grimm, Habermas (1995: 307) believes the EU's continental member-states should manage that. So do I.

9 That Belgium's constitutional endeavours have a wider relevance for Europe and beyond is often noted by foreign observers. For example, the Canadian political scientist Kenneth McRay (1989: 205) warns that "if [Belgium's] arduous search for a stable, plurilingual society were to fail or to be abandoned, this would be a loss not only for Belgium and for Europe generally, but also for other plurilingual and multilingual societies that pursue the same difficult quest." The German sociolinguist Florian Coulmas (1991: 3) claims that Belgium's transformation into a federal state "may eventually prove to be conducive to European integration in an unforeseen manner. Although King Baudouin contends that the new constitution guarantees a solid national state and excludes any form of separatism, many Belgian politicians see it as weakening the State. And this is just, some people think, what the [European] community needs." Finally, the British political scientist Vernon Bogdanor (1997: 66) interprets both Belgium and the European Union as "quasi-federal" attempts to make a multinational community viable, while noting that "the success of the European Union, like that of Belgian federalism, must remain a matter of some doubt". 
and democracy but also social justice in today's Europe. So, must Europe be Belgian? In this rather qualified, somewhat far-fetched sense, yes indeed it must. 


\section{References}

Anderson, Benedict R.O. 1993. "Nationalism", in The Oxford Companion to the Politics of the World (Joel Krieger ed.), Oxford: Oxford University Press, 614619.

Beelen, Staf, De Poorter, Laurent, Haeyaert, Philippe \& Vandenbroeke, Chris. 1993. Geschiedenis van de Vlaamse ontvoogding. Deurne: MIM.

Bogdanor, Vernon. 1997. "Forms of Autonomy and the Protection of Minorities", Daedalus 126 (2), 65-87.

Brans, Marleen. 1993. "High-Tech Problem Solving in a Multi-Cultural State: The Case of Brussels", Dutch Crossing. A Journal of Low Countries Studies 49, 3-28.

BRTN. 1996. Continukijkonderzoek, Brussel: BRTN Studiedienst, februari 1996.

Coulmas, Florian. 1991. "European Integration and the Idea of a National Language. Ideological roots and economic consequences", in A Language Policy for the European Community (Florian Coulmas ed.), Berlin: Mouton de Gruyter, 1991, $1-37$.

De Ridder, Paul. 1988. Het andere Brussel. Een afrekening met vooroordelen. Wommelgem: Den Gulden Engel.

Destrée, Jules. 1923. Wallons et Flamands. La Querelle linguistique en Belgique. Paris: Plon.

Dewachter, Wilfried. 1996. "La Belgique d'aujourd'hui comme société politique", in La Belgique. La Force de la désunion (A. Dieckhoff ed.), Bruxelles: Complexe, 105-142.

Engels, Friedrich. 1848. "The Danish-Prussian Armistice", in K. Marx \& F. Engels, Collected Works Vol.7, London: Lawrence \& Wishart, 1977, 421-425.

Fondation francophone de Belgique. 1997. Etude sur l'identité francophone en région de Bruxelles-capitale. Bruxelles, décembre 1997.

Garrett, Geoffrey. 1998. " Global Markets and National Politics: Collision Course or Virtuous Circle?", International Organization 52, 787-824.

Gellner, Ernest. 1983. Nations and Nationalism. Oxford: Blackwell.

Grimm, Dieter. 1995. "Does Europe Need a Constitution?", European Law Journal 1 (3), 282-302.

Habermas, Jürgen. 1995. "Remarks on Dieter Grimm's 'Does Europe Need a Constitution?'", European Law Journal 1 (3), 303-307. 
Hamilton, Alexander, Madison, James and Jay, John. 1788. Federalist Papers, New York: The New American Library of World Literature, 1964.

Kymlicka, Will. 1999. "Citizenship in an Era of Globalization: Comment on Held", in Democracy's Edges (Shapiro, Ian \& Hacker-Cordón eds.). Cambridge:

Cambridge University Press, 112-126.

Laponce, Jean A. 1984. Langue et territoire. Québec: Presses uniersitaires de Laval. (English translation: Languages and their Territories. Toronto: University of Toronto Press, 1987.)

Laponce, Jean A. 1993. "Do Languages Behave Like Animals?", International Journal for the Sociology of Language 103, 19-30.

Laponce, Jean A. 1996. "Minority Languages in Canada: Their Fate and Survival Strategies", Language, Culture and Values in Canada at the Dawn of the 21st Century (André Lapierre, Patricia Smart \& Pierre Savard eds.), Ottawa: Carleton University Press, 75-89.

Marx, Karl. 1848a. "The 'Model State' of Belgium", in K. Marx \& F. Engels, Collected Works Vol.7, London: Lawrence \& Wishart, 1977, 333-36.

McRay, K.D. 1989. "Plurilingual States and Capital Cities", in Het Probleem Brussel sinds Hertoginnedal (Els Witte ed.), Brussel: V.U.B., 193-206.

Mill, John Stuart. 1861. Considerations on Representative Governement, in On Liberty and Other Essays (J. Gray ed.), Oxford: Oxford University Press, 1991, 203-467.

Papaux, Alexandre. 1997. "Droit des langues en Suisse: Etat des lieux", Revue suisse de science politique 3 (2), 131-134.

Poulain, Michel \& Foulon, Michel. 1998. "Frontières linguistiques, migrations et distribution spatiale des noms de famille en Belgique", L'Espace géographique 1, 53-62.

Renner, Karl. 1918. Das Selbstbestimmungsrecht der Nationen, in besonderer Anwendung auf Oesterreich. Leipzig \& Wien: Franz Deuticke.

Scharpf, Fritz. 1999. "The Viability of Advanced Welfare States in the International Economy. Vulnerabilities and Options", Köln: Max Planck Institute for the Study of Societies, 39p.

Schmitt, Carl. 1926. Die geistesgeschichtiche Lage des heutigen Parlamentarismus ( $2^{\text {nd }}$ edition). Berlin: Duncker \& Humblot, 1963.

Strange, Susan. 1992. "Ethics and the Movement of Money: Realist Approaches", in Free Movement (B. Barry \& R. Goodin eds.), Hemel-Hempstead: HarvesterWheatsheaf, 232-247. 
Van Parijs, Philippe. 1999. "Just Health Care and the Two Solidarities", Harvard Center for Population and Development Studies, Working Paper 99.03, 18p.

Van Parijs, Philippe. 2000a. "The Ground Floor of the World. On the Socio-Economic Consequences of Linguistic Globalisation", in International Political Science Review 21 (2), 217-233.

Van Parijs, Philippe. 2000b. "Power-Sharing versus Border-Crossing in Severely Divided Societies", in Designing Democratic Institutions (Steven Macedo \& Ian Shapiro eds.), New York: NYU Press, forthcoming.

Vandenbroucke, Frank. 1998. Globalization, Inequality and Social Democracy. A Survey. London: IPPR.

Willems, Leonard. 1902. "Over twee antivlaamsche brieven toegeschreven aan Minister Rogier", in Verslagen en Mededeelingen der Koninklijke Vlaamsche Academie voor Taal- en Letterkunde, Gent: A. Siffer, 53-90. 


\section{Appendix}

\section{Belgium: a few dates}

1585

1795

1815

1830

1839

1893

1898

1899

1930

1932

1954

1962

1968

1970

1993

Reconquest of Antwerp by the Spanish army, key event for the division of the Lower Countries between the Republic of the United Provinces in the North (later to become the Kingdom of the Netherlands) and the Southern provinces, which will remain under Habsburg rule for another two centuries Invasion of Belgium by the French revolutionary army and annexation by France

Incorporation of Belgium into the Kingdom of the Netherlands (Treaty of Vienna)

Independence from the Netherlands. French chosen as the sole official language Recognition of Belgium's independence at the cost of part of the provinces of Limburg (Maastricht) and Luxemburg (to become the Grand Duchy) (Treaty of London)

Universal male suffrage

Official equality between French and Dutch as official languages

First country to introduce proportional representation

First Dutch-language University (Ghent)

Official unilingualism in Flanders and Wallonia

Last expansion of the territory of Brussels (19 communes)

Recognition of the fixity of linguistic borders, tempered by "facilities" in a number of communes

Decision to transfer the Université catholique de Louvain out of Flanders and partition of the chritian-democratic party (the other national gfparties will follow in 1972 and 1978)

Creation of the Communities and Regions

Official transformation of Belgium into a federal state (new constitution promulgated on 17.2.1994) 